Pamela McKenzie

University of Western Ontario

Cameron Hoffman

University of Western Ontario

Rosamund Stooke

University of Western Ontario

\title{
Paper: Librarians and/as teachers: A discourse analysis of the representation of librarians and formal educators in the professional literature for public, academic, and school librarians
}

\begin{abstract}
Public, school, and academic librarians work with formal educators to support student literacy learning across the formal education spectrum. This paper analyzes representations of librarians and formal educators in the professional literature for all three types of librarians. We identify common patterns and relate these to more globalized discourses.

Résumé: Les bibliothécaires en milieu public, scolaire et universitaire travaillent avec des enseignants professionnels à l'enseignement des compétences informationnelles dans le cadre du cheminement scolaire. Cette communication analyse les représentations des bibliothécaires et des enseignants professionnels dans la littérature professionnelle pour les trois types de bibliothécaires. Nous pouvons relever des modèles communs et les mettre en lien avec des discours plus internationaux.
\end{abstract}

\section{Introduction}

Librarians work in and with educational institutions to support students' literacy learning throughout the course of formal education. Librarians' work complements the work of formal teachers at all levels. Teacher-librarians work with K-12 classroom teachers to support literacyrelated curriculum objectives. Academic librarians create stand-alone and integrated instruction sessions to foster information literacy learning. Even public librarians, whose work is not institutionally linked with formal education organizations, provide literacy support for young children with the goal of preparing them for formal education. ALA president Leslie Burger observed that part of the public library's mandate is to "build the early literacy skills that are so essential to ensuring that children are ready to read by the time they enter kindergarten" (Burger, 2008, 45).

The professional literature for public, academic, and teacher-librarians alike contains numerous representations of librarians' instructional roles in relation to the roles of the classroom teachers and university professors with whom they work. This paper presents an initial analysis of those local representations, identifying common elements and relating them to more global issues of the professional identity of librarians across the three specializations. 


\section{Literature review}

The professional status of librarians has received a great deal of sustained attention (e.g., Harris, 1992). The relationship between librarians' educational work and the work of formal teachers and professors has likewise been studied by three previous CAIS presentations. Given and Julien (2003) analyzed posts to an information literacy listserv (BI-L/ILI-L) to identify patterns in academic librarians' "unscripted" comments on how best to work with faculty. They identified the discursive strategies librarians used to describe themselves and faculty and found that librarians represented faculty in largely negative ways. While posters understood both librarians and faculty to share the goal of educating students, posts largely highlighted the experiential distinctions between the two groups. Librarian posters represented faculty support as integral to their own instructional work, but positioned faculty as unaware or disrespectful of the complexity and importance of information literacy skills and hence of librarians' expertise. Issues of control over instructional objectives also featured in their representations. Similar findings are also borne out in interviews with librarians themselves (e.g., Julien \& Pecoskie, 2009; Sundin et al., 2008).

Hoffman and Polkinghorne (2010) found that instructional librarians' posts about the social web on ILI-L were informed by competing impulses. While the social web has the potential to enrich librarians' information literacy instruction, it also presents fundamental challenges to their teaching practices. These authors found that a discourse of control was predominant in posts, both with respect to order and control over resources and collections, and related to librarians' personal identities and their instructional roles.

At the other end of the educational spectrum, McKenzie and Stooke (2001) analyzed representations of librarians, teachers and parents in the professional literature for public librarians and classroom teachers published between 1990 and 2000. They found that authors in both LIS and education carved up the universe of literacy expertise into three domains over which each constituent group could lay primary claim. Librarians' expertise was built on claims of knowledge about materials, teachers' on knowledge about pedagogical knowledge, and parents' on access to and knowledge of specific children. The allocation of these domains of expertise was not for the most part disputed between the discourse communities. What was disputed was the value of each domain to emergent literacy. Again, librarians described teachers as unaware and potentially dismissive of librarians’ particular expertise.

These three previous papers identify similar themes. To date, however, analysis has focused on a single library setting (academic, school, public) at a time. This paper is a first step toward both updating and integrating these studies by surveying the more recent literature and identifying common elements and distinctions in librarians' professional writing on their relationship with formal educators across the educational spectrum.

\section{Theoretical approach and methodology}

As did the authors of the studies mentioned above, this paper takes a social constructionist discourse analytic approach. Julien and Given (2003) used Social Positioning Theory (Harré and van Langenhove 1999) as their analytic frame. McKenzie and Stooke (2001) used Jonathan 
Potter's concept of "category entitlement," the authority to speak about certain issues by virtue of membership in a specific group (Potter 1996, 132). Both approaches allow for an analysis of the ways that writers describe different professional roles and their competencies and explain how different roles relate to one another. Hoffman and Polkinghorne (2010) used critical discourse analysis, a strategy focuses less on the construction of the individual account than on its embeddedness within macro-level discourses (see also Tuominen 1997).

This paper builds on the previous studies by analyzing the ways librarians and teachers/professors are represented across the educational spectrum in the professional LIS literature. Whereas Julien and Given (2003) and Hoffman and Polkinghorne (2010) selected listserv postings for their status as "unscripted" comments, this article will analyze published texts because these represent views that have been vetted and accepted by other members of the profession - or "community of justification" (Sundin et al., 2008) -- through the publication process.

We searched the database LISA for the years 2001-2011 and the subject terms Literacy OR Reading Promotion combined with free-text terms teacher* or professor* or instructor* and hand-searched the resulting set for articles written by or for practitioners. We eliminated numerous false hits (e.g., those describing teacher-librarians but not describing librarians' relationship to teachers). For this presentation we have selected those that talk at some length about the role of the librarian relative to that of the formal teacher. Although many empirical articles and descriptions of professional practice included personal positioning (Harré \& van Langenhove, 1999) of individual teachers and librarians, we chose to focus on a smaller sample of articles that include moral positioning (Harré \& van Langenhove, 1999) of librarians and teachers as professional groups such as general descriptions or prescriptions about their relative roles. Our sample consists of approximately 50 articles including opinion or position papers, empirical articles and descriptions of practice.

We analyzed our sample by identifying the ways that the authors positioned (Harré \& van Langenhove, 1999) librarians as educators and in relation to teachers/professors. We paid attention to how writers constructed and contested the category entitlement (Potter, 1996) of the different professions and what criteria are required for someone to take on the role of 'teacher.'

We found that the literature represented teachers and librarians on a spectrum of differentiation from 'two solitudes' living and working in fundamentally different worlds, to complementary professions providing different but equally valuable expertise, to undifferentiated equality: “we're all teachers." Teachers and librarians were further differentiated along multiple lines, including education, nature of expertise, and status within the organization.

Authors' positioning of librarians and teachers/professors in relation to one another drew on already established subject positions (e.g., Tuominen, 1997) situated within broader discourses. A partnership discourse focused on equality or complementarity and was notable for the absence of conflict. Other forms of positioning emphasized differences in knowledge and status between teachers and librarians. For example, a moralistic discourse of good and evil positioned the 
librarian as preaching information literacy to teachers in a morally threatening technological context (Hoffman \& Polkinghorne, 2009), a militaristic discourse emphasized conquest, control, and fear (Radford \& Radford, 2001), and a courtship discourse positioned the librarian as a suitor, seeking in vain to secure the attentions of the teacher.

Finally, we found that representations of librarians and teachers were deeply intertwined with discussions of the nature and role of technology. Authors consistently situated the librarian/teacher relationship within a "new information age" of constant technological and societal change in which information literacy is a set of competencies required by students for academic and possibly lifelong success. Technology served as a rhetorical tool to support the multiple forms of positioning, and was itself represented variously as a threat to the very existence of librarianship, as a tool to be deployed, and as the profession's only hope for the future.

\section{Conclusion}

Although there were differences, the same discourses appeared across educational settings. The positioning of librarians in relation to teachers in the LIS professional literature is multifaceted, deeply ambivalent, and intertwined with discussions of the nature, meaning, and role of technology, information literacy, and expert knowledge.

\section{References}

Burger, Leslie. 2008. All seasons \& all reasons. American Libraries, 39(3), 44-40. Harré, Rom and Luc van Langenhove. 1999. Positioning theory. Oxford: Blackwell. Harris, Roma M. 1992. Librarianship: the erosion of a woman's profession. Norwood, NJ: Ablex.

Hoffman, Cameron and Sarah Polkinghorne. 2009. Crown jewel or pure evil? Wikipedia through an information literacy lens. Feliciter 55. 3: 101-103.

Hoffman, Cameron and Sarah Polkinghorne. 2010. Discourse, identity, practice: analyzing instruction librarians' conversations about information literacy and the social Web. Information Science: Synergy through Diversity. $38^{\text {th }}$ annual conference of the Canadian Association for Information Science, Concordia University, Montreal, Quebec, Canada. June 2 - 4, 2010. Proceedings Editors: Elaine Ménard, Valerie Nesset and Sabine Mas

Julien, Heidi and Lisa M. Given. 2003. Faculty-librarian relationships in the information literacy context: a content analysis of librarians' expressed attitudes and experiences. Canadian Journal of Information and Library Science 27. 3 (Sep): 65-87.

Julien, Heidi and Jen (JL) Pecoskie. 2009. Librarians' experiences of the teaching role: grounded in campus experiences. Library \& Information Science Research 31: 149-154.

McKenzie, Pamela J. and Rosamund K. Stooke. 2001. Who is entitled to be a literacy expert? Category entitlements of parents and professionals in the literature on children's literacy learning. Beyond The Web: Technologies, Knowledge and People. $29^{\text {th }}$ annual conference of the Canadian Association for Information Science, Université Laval, Quebec City, Quebec. May 27 - 29, 2001. Proceedings Editor: D. Grant Campbell. Potter, Jonathan. 1996. Representing reality. New York: Routledge. 
Radford, Gary P. and Marie L. Radford. 2001. Libraries, librarians, and the discourse of fear. Library Quarterly, 71(3), 299-329.

Sundin, Olof, Louise Limberg and Anna Lundh. 2008. Constructing librarians' information literacy expertise in the domain of nursing. Journal of Librarianship and Information Science 40(1): 21-30.

Tuominen, Kimmo. 1997. User-centered discourse: an analysis of the subject positions of the user and the librarian. Library Quarterly, 67(4), 350-71. 